\title{
Persepsi Nazhir dalam Pendaftaran Tanah Wakaf
}

\author{
Variahatul Ratnasari ${ }^{1 *}$, Ahmad Ajib Ridlwan ${ }^{2}$ \\ ${ }^{1,2}$ Program Studi Ekonomi Islam, Fakultas Ekonomi, Universitas Negeri Surabaya, Indonesia
}

Masuk: 4 Juli 2019; Diterima: 17 Desember 2019; Terbit: 20 Desember 2019

\begin{abstract}
This study aims to determine the relationship between Nazhir's knowledge and attitude in the Krian District of Sidoarjo Regency with their behavior in the registration of waqf land. This research was conducted with an associative descriptive approach where the data obtained from the questionnaire in the form of numbers. The number of samples used in this study amounted to 80 respondents who are managers of land waqf in Krian District, Sidoarjo Regency and use simple random sampling techniques. This study uses a questionnaire with a Likert scale. The results of this study indicate that Nazhir's knowledge and attitude related to the procedure for registering waqf land has a moderate and significant correlation with Nazhir's behavior in carrying out the act of registering waqf land. That is due to the lack of socialization from authorized institutions to the community to manage the administration of waqf land. The knowledge and attitude possessed by Nazhir regarding the registration of waqfland would increase Nazhir's behavior or actions in registering the waqf land. This research was conducted to prevent future disputes caused by the absence of written evidence as waqfland.
\end{abstract}

Keywords: knowledge, attitude, behavior, nazhir, registration of waqfland

\begin{abstract}
Abstrak
Penelitian ini bertujuan untuk mengetahui hubungan pengetahuan dan sikap Nazhir di Kecamatan Krian Kabupaten Sidoarjo dengan perilaku mereka dalam pendaftaran tanah wakaf. Penelitian ini dilakukan dengan pendekatan deskriptif asosiatif dimana data yang diperoleh dari kuisioner berupa angka. Jumlah sampel yang digunakan pada penelitian ini berjumlah 80 responden yang merupakan pengelola wakaf tanah di Kecamatan Krian Kabupaten Sidoarjo dan menggunakan teknik simple random sampling. Penelitian ini menggunakan kuisioner dengan skala likert. Hasil penelitian ini menunjukkan bahwa pengetahuan dan sikap Nazhir terkait tata cara pendaftaran tanah wakaf memiliki korelasi sedang dan signifikan dengan perilaku Nazhir dalam melakukan tindakan pendaftaran tanah wakaf. Hal itu dikarenakan kurangnya sosialisasi dari lembaga yang berwenang kepada masyarakat untuk mengelola administrasi tanah wakaf. Adanya pengetahuan serta sikap yang dimiliki Nazhir terkait pendaftaran tanah wakaf akan meningkatkan perilaku atau tindakan Nazhir dalam mendaftarkan tanah wakaf. Penelitian ini dilakukan untuk mencegah adanya persengketaan yang terjadi dikemudian hari yang disebabkan karena tidak adanya bukti tertulis sebagai tanah wakaf.
\end{abstract}

Kata Kunci: pengetahuan, sikap, perilaku, nazhir, pendaftaran tanah wakaf 


\section{PENDAHULUAN}

Wakaf merupakan suatu ibadah yang bersifat sosial dilakukan dengan memisahkan sebagian harta yang dimiliki dan dilembagakan untuk kepentingan peribadatan sesuai dengan syariat Islam (Abdullah \& Qodin, 2014). Wakaf memiliki kedudukan terpenting dalam ajaran agama Islam, seperti halnya amalan zakat dan sedekah. Wakaf juga tergolong ibadah maliyah. Artinya, wakaf merupakan ibadah yang pahalanya tidak dapat terputus sepanjang harta wakaf masih dapat dimanfaatkan oleh kebutuhan umat. Wakaf dapat meliputi berbagai benda asalkan benda tersebut bersifat tetap sehingga tidak habis ketika diambil manfaatnya (Habibi \& Yudha, 2017). Fungsi sosial dari wakaf harus memberikan manfaat, baik langsung maupun tidak langsung kepada masyarakat karena dalam harta seseorang terdapat hak orang lain (Saidi, Pagar, \& Jamil, 2018). Adapun salah satu obyek dari wakaf adalah tanah.

Tanah merupakan salah satu media yang terpenting bagi kehidupan masyarakat. Tanah memiliki banyak fungsi diantaranya sebagai kegiatan sosial, tempat ibadah, maupun taman pendidikan (Pratama, Muhyidin, \& Islamiyati, 2016). Tanah wakaf menjad potensi yang menarik apabila dikelola secara optimal. Keberadaan tanah wakaf sering dianggap sebagai permasalahan apabila tidak memiliki bukti tertulis yang menyatakan harta wakaf. Ketentuan tersebut telah diatur dalam Peraturan Pemerintah No. 28 Tahun 1977 tentang Perwakafan Tanah Milik (Fadhilah, 2011).

Indonesia merupakan negara yang berpenduduk Muslim terbesar. Jumlah penduduk Muslim tersebut merupakan sebuah potensi yang dapat dimanfaatkan untuk menerapkan peran perwakafan (Hazami, 2016). Berdasarkan data dari Direktorat Pemberdayaan Zakat dan Wakaf (siwak.kemenag.go.id) pada bulan Februari 2019, terdapat 354.494 lokasi tanah wakaf yang tersebar di seluruh Indonesia dengan luas mencapai 48.477,25 Ha. Namun, tanah wakaf yang tersebar di Indonesia belum seluruhnya memiliki sertifikat tanah wakaf, yakni masih terdapat $37,21 \%$ yang belum memiliki sertifikat wakaf. Hal itulah yang sering menimbulkan permasalahan praktik perwakafan pada masyarakat. Banyak tanah wakaf yang tidak disertai ikrar wakaf dan tidak ditindaklajuti dengan pembuatan sertifikat wakaf. Kondisi ini yang mengakibatkan terjadinya tanah wakaf tidak memiliki status hukum yang kuat, sehingga jika terjadi permasalahan mengenai kepemilikan tanah wakaf akan sulit diselesaikan (Hendrawati \& Islamiyati, 2018). Ada berbagai permasalahan yang mengakibatkan tanah wakaf belum bermanfaat secara optimal. Permasalahan tersebut dikarenakan kurangnya pengetahuan dan pemahaman pengelola wakaf (Nazhir) terkait administrasi tanah wakaf. Sebagian besar tanah wakaf di Indonesia dimanfaatkan sebagai tempat ibadah (Huda, Anggraini, Rini, Hudori, \& Mardoni, 2014). Padahal, jika tanah tersebut dikelola secara produktif dapat digunakan sebagai alternatifuntuk membantu meningkatkan kemiskinan. 
Menurut Juliana (2017), pengetahuan Nazhir menjadi faktor terpenting dalam meningkatkan pengelolaan wakaf produktif. Pengetahuan akan menentukan sikap positif bagi Nazhir dan dapat pula menggerakkan perilaku positif Nazhir dalam menyikapi pemberdayaan wakaf produktif. Menurut Zuhrinal dan Nawawi (2011) sikap dapat mempengaruhi kecenderungan masyarakat untuk berwakaf. Perilaku Nazhir juga dapat dijelaskan melalui pengetahuan, sikap dan tindakan yang dilakukan dalam mengelola perwakafan. Perilaku indvidu memiliki hubungan erat dengan pengetahuan dan sikap yang dimiliki seseorang (Haqqy, Busaini, \& Rois, 2017). Sedangkan menurut Junaidi (2015), kepercayaan juga menjadi faktor penting dalam mempengaruhi perilaku Nazhir untuk mendaftarkan tanah wakaf. Kepercayaan yang dimiliki masyarakat masih sangat kental dan tradisional. Hal itulah yang menjadikan masyarakat sulit untuk menerima hal baru meskipun pengetahuan yang dimiliki Nazhir sudah cukup baik. Akibatnya, tanah wakaf mengalami penghambatan efektifitas dalam pensertifikatan. Permasalahan tersebut seringkali terjadi pada daerah yang memiliki jumlah tanah wakaf yang belum bersertifikat.

Kabupaten Sidoarjo merupakan salah satu Kabupaten yang terletak di Jawa Timur dan memiliki potensi cukup besar dalam perwakafan tanah. Jumlah tanah wakaf di Kabupaten Sidoarjo mencapai 2.781 wilayah tanah wakaf yang tersebar di 18 Kecamatan. Adapun jumlah tanah wakaf pada setiap Kecamatan Sidoarjo dapat dilihat melalui tabel berikut:

Tabel 1. Jumlah Tanah Wakaf di Kabupaten Sidoarjo

\begin{tabular}{clccc}
\hline No. & Kecamatan & Jumlah & Sudah Sertifikat & Belum Sertifikat \\
\hline 1. & Sidoarjo & 73 & 73 & 0 \\
2. & Buduran & 129 & 68 & 61 \\
3. & Candi & 253 & 203 & 50 \\
4. & Tanggulangin & 216 & 191 & 25 \\
5. & Porong & 174 & 169 & 5 \\
6. & Jabon & 119 & 107 & 12 \\
7. & Krembung & 299 & 166 & 133 \\
8. & Tulangan & 240 & 184 & 56 \\
9. & Wonoayu & 229 & 130 & 99 \\
10. & Krian & 368 & 171 & 197 \\
11. & Prambon & 110 & 107 & 3 \\
12. & Bl. Bendo & 238 & 117 & 121 \\
13. & Tarik & 18 & 14 & 4 \\
14. & Sukodono & 73 & 69 & 4
\end{tabular}




\begin{tabular}{llccc} 
15. & Taman & 219 & 189 & 30 \\
16. & Waru & 10 & 0 & 10 \\
17. & Gedangan & 5 & 5 & 0 \\
18. & Sedati & 8 & 8 & 0 \\
\hline & Jumlah & $\mathbf{2 . 7 8 1}$ & $\mathbf{1 . 9 7 1}$ & $\mathbf{8 1 0}$ \\
\hline
\end{tabular}

Sumber : Sistem Informasi Wakaf, 2019 (diolah)

Pada Tabel 1 menunjukkan bahwa Kecamatan Krian merupakan salah satu kecamatan yang memiliki tanah wakaf terbesar di Kabupaten Sidoarjo dengan jumlah 368 lokasi tanah wakaf. Namun, sebanyak 197 tanah wakaf belum memiliki sertifikat wakaf.

Menurut observasi yang dilakukan oleh penulis pada bulan April 2019 di Kecamatan Krian, penerapan perwakafan saat ini masih berdasarkan kepercayaan kepada seseorang atau suatu lembaga. Ikrar perwakafan di Kecamatan Krian hanya menggunakan ucapan dan disaksikan oleh beberapa pihak. Pengetahuan terkait pendaftaran tanah wakaf yang dimiliki oleh pengelola wakaf juga sangat minim. Sehingga timbullah permasalahan sengketa tanah wakaf antara pihak keluarga wakif dengan masyarakat setempat karena pengelola tanah wakaf telah meninggal dunia dan tidak dibuktikan secara tertulis. Adapun kebijakan yang dilakukan yaitu mendaftarkan tanah wakaf secara massal untuk mencegah persengketaan tanah wakaf.

\section{Pengetahuan}

Pengetahuan diartikan sebagai hasil tahu setelah seseorang memahami suatu objek. Pengetahuan seseorang akan membentuk suatu sikap yang sesuai dengan pengetahuan yang diterimanya, baik sikap positif maupun sikap negatif. Pengetahuan juga mengandung aspek positif dan aspek negatif. Kedua aspek tersebut akan mempengaruhi sikap manusia. Pengetahuan dapat diperoleh melalui 2 (dua) cara, yaitu pendidikan formal dan nonformal. Pengetahuan seseorang akan semakin luas apabila dibekali dengan pendidikan yang tinggi. Akan tetapi, apabila seseorang yang memiliki pendidikan rendah, bukan berarti mutlak memiliki pengetahuan yang rendah (Wawan \& Dewi, 2014). Sehingga, peningkatan pengetahuan tidak hanya diperoleh melalui pendidikan formal saja namun juga bisa diperoleh melalui pendidikan nonformal.

\section{Sikap}

Menurut Azwar (2002), sikap merupakan bentuk interaksi sosial yang dialami oleh setiap individu. Interaksi sosial ini mengandung arti lebih dari adanya kontak sosial dan hubungan antar individu. Dasar pembentukan sikap juga dipengaruhi oleh pengalaman pribadi, dimana sikap akan lebih mudah terbentuk apabila pengalaman yang terjadi melibatkan 
perasaan. Menurut Wawan dan Dewi (2014), sikap dapat membantu seseorang memahami proses kesadaran dalam menentukan tindakan nyata yang mungkin dilakukan individu. Sehingga melalui sikap, seseorang dapat melakukan evaluasi terhadap objek atau subjek yang telah diamati sebelumnya.

\section{Perilaku}

Perilaku merupakan keaktifan seseorang dalam merespon perkembangan di sekitar dan dipengaruhi oleh sikap, etika, persuasi atau genetika (Juliana, 2017). Adapun perilaku seseorang dibedakan kedalam perilaku wajar, dapat diterima, dan perilaku menyimpang. Tindakan sosial manusia yang mendasar ialah ketika berperilaku yang tidak ditujukan kepada orang lain. Perilaku manusia dibentuk melalui kekuatan psikologis yaitu motivasi yang dapat mendorong seseorang untuk lebih dewasa (Simamora, 2002).

\section{Kerangka Pemikiran}

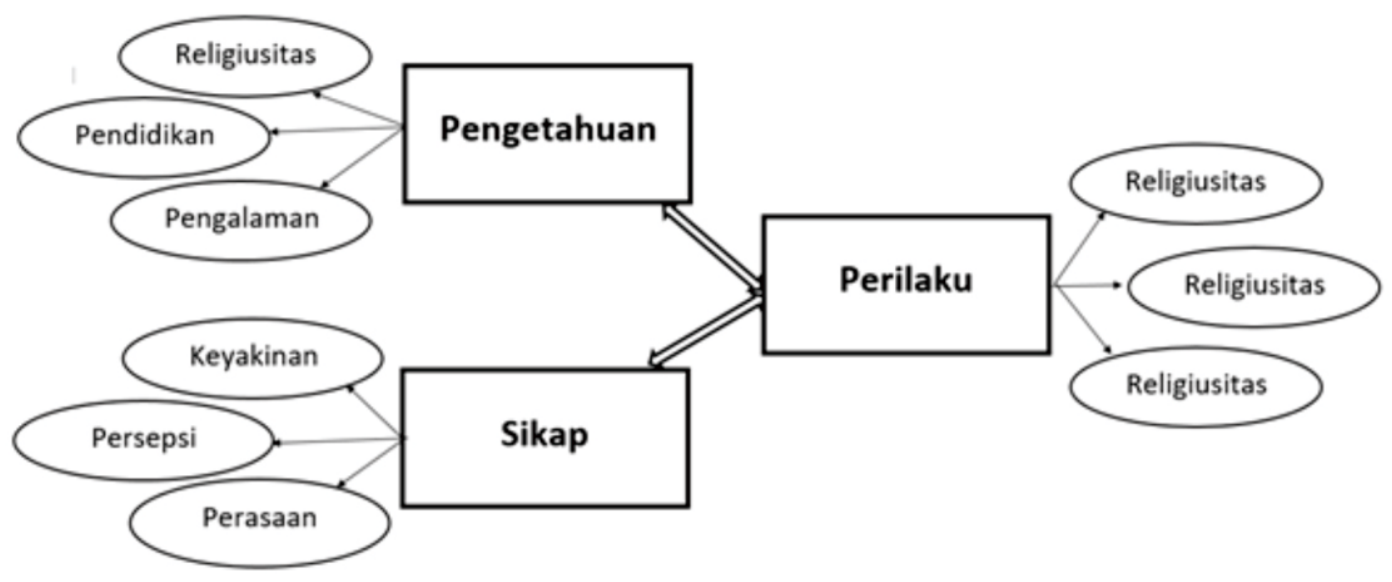

Gambar 1. Kerangka Pemikiran

Pada Gambar 1 menyimpulkan bahwa pengetahuan seseorang dapat diukur melalui pendidikan. Seseorang yang berpendidikan tinggi maka kemungkinan besar seseorang tersebut akan memiliki pengetahuan yang luas. Pengetahuan yang dimiliki seseorang tidak hanya pengetahuan yang bersifat umum, melainkan juga pengetahuan agama yang dianutnya atau tingkat religiusitas. Menurut Maulida (2013), tingkat religiusitas dapat mempengaruhi perilaku seseorang dalam beramal karena adanya suatu kepercayaan seseorang terhadap objek. Sehingga dihasilkan bahwa religiusitas berpengaruh signifikan terhadap perilaku beramal, dimana hasil penelitian menunjukkan bahwa variabel religiusitas memiliki kontribusi yang baik dalam berperilaku. Adanya sebuah pengalaman juga akan memberikan pengetahuan baru atau menambah pengetahuan yang dimiliki oleh seseorang. Sehingga dari pengetahuan yang dimiliki seseorang akan membentuk suatu perilaku sesuai dengan pengetahuan yang dimiliki. 
Pernyataan tersebut sejalan dengan penelitian Pakpahan (2017) yang menggambarkan bahwa pengetahuan merupakan informasi yang tersimpan dalam otak manusia. Pengetahuan juga dapat merubah perilaku manusia berdasarkan dengan pengalaman yang diperoleh. Dengan memiliki banyak pengalaman, maka setiap manusia memiliki pengetahuan yang baik. Sehingga dari pernyataan tersebut, pengetahuan dapat menentukan sikap dan perilaku diukur melalui pendidikan dan pengalaman.

Pada penelitian ini, sikap diukur melalui keyakinan seseorang terhadap suatu objek. Menurut Mustadi (2016) ketika menghadapi dan merespon sesuatu akan diwarnai oleh nilainilai yang diyakininya, seperti keyakinan agama. Pada penelitian ini, sebagian besar Nazhir di Kecamatan Krian Kabupaten Sidoarjo tidak meyakini sepenuhnya bahwa pendaftaran tanah wakaf itu penting untuk masa depan tanah wakaf. Sehingga, dalam hal ini nilai agama Islam juga berpengaruh terhadap pembentukan sikap dan penentuan perilaku seseorang. Menurut Gerungan (2004) apabila suatu sikap telah terbentuk dalam diri manusia, sikap itu akan turut menentukan tingkah lakunya terhadap objek sikapnya. Dengan kata lain, adanya sikap menyebabkan manusia akan bertindak secara khas terhadap suatu objek. Mardeli (2016) juga berpendapat bahwa sikap dapat diukur melalui perasaan atau emosional seseorang melalui perubahan perilaku atau tingkah laku seseorang.

\section{METODE}

Penelitian ini menggunakan jenis penelitian kuantitatif. Data yang telah terkumpul akan dianalisis menggunakan statistik deskriptif (Sugiyono, 2018). Penelitian ini berkenaan tentang hubungan antara pengetahuan dan sikap dengan perilaku Nazhir dalam pendaftaran tanah wakaf sehingga termasuk kedalam penelitian korelasional, yang memiliki tujuan untuk mengetahui ada atau tidaknya hubungan antarvariabel. Populasi yang digunakan pada penelitian ini adalah seluruh Nazhir tanah wakaf di Kecamatan Krian Kabupaten Sidoarjo. Sedangkan, sampel yang digunakan sejumlah 80 responden dengan menggunakan rumus Yamane (Hamidi, 2010) sebagai berikut:

$$
\mathbf{n}=\frac{\mathbf{N}}{1+\left(\mathrm{N} \mathrm{x} \mathrm{e}^{2}\right)}
$$

Dengan keterangan :

$\mathrm{n}=$ Jumlah elemen atau sampel

$\mathrm{N}=$ Jumlah elemen atau anggota populasi $=368$

$\mathrm{e}=$ Error level $=0.10$ 
Sehingga, perhitungan jumlah sampel pada penelitian ini sebagai berikut:

$\mathrm{n}=368 / 1+368 \times(0,1)^{2}$

$\mathrm{n}=368 / 4,68$

$\mathrm{n}=78,6$

Adapun teknik pengambilan sampel pada penelitian ini menggunakan sample random sampling, pengambilan sampel dilakukan secara acak dan tidak memperhatikan karakteristik yang ada pada populasi.

Lokasi pada penelitian ini adalah kecamatan Krian Kabupaten Sidoarjo yang merupakan salah satu Kecamatan di Sidoarjo yang memiliki jumlah tanah wakaf belum bersertifikat terbanyak. Waktu yang digunakan selama penelitian ialah selama 1 bulan, yaitu pada bulan April 2019. Teknik pengumpulan data pada penelitian ini dilakukan agar penelitian dapat berjalan dengan sistematik. Adapun teknik pengumpulan datanya melalui wawancara dan penyebaran kuesioner atau angket.

Penelitian ini menggunakan data primer dan data sekunder. Data primer diperoleh melalui kuesioner atau angket yang disebarkan kepada 80 responden, dan data sekunder diperoleh melalui website. Adapun karakteristik responden pada penelitian ini yaitu melalui pendidikan, usia, dan jenis pekerjaannya. Melalui riwayat pendidikan yang dimiliki oleh Nazhir, dapat diketahui seberapa besar pengetahuan terkait administrasi tanah wakaf khususnya melalui pendidikan Islam. Usia menjadi karakteristik karena semakin tinggi usia Nazhir belum tentu memiliki pengetahuan yang baik dalam perwakafan khususnya administrasi tanah wakaf. Jenis pekerjaan juga menjadi karakteristik responden untuk mengetahui apakah peran Nazhir sebagai pengelola wakaf adalah pekerjaan sampingan atau pekerjaan utama. Jenis kuesioner yang digunakan termasuk jenis kuesioner tertutup menggunakan empat poin skala Likert $(4=$ sangat setuju, $3=$ setuju, $2=$ tidak setuju, dan $1=$ setuju) untuk menghindari jawaban keragu-raguan dari responden. Instrumen dalam penelitian ini diuji menggunakan uji validitas, uji reliabilitas, dan uji normalitas. Sedangkan, untuk uji hipotesis penelitian ini menggunakan uji koefisien korelasi Kendall's dan uji korelasi berganda untuk mengukur kekuatan hubungan antara pengetahuan dan sikap dengan perilaku. 


\section{HASIL DAN PEMBAHASAN}

\section{Uji Korelasi Kendall's}

Pada penelitian ini, uji korelasi kendall's digunakan untuk mengetahui seberapa kuat variabel bebas dengan variabel terikat. Adapun hasil uji korelasi dapat dilihat pada tabel berikut:

Tabel 2. Hasil Uji Korelasi Pengetahuan dengan Perilaku

\begin{tabular}{|c|c|c|c|}
\hline & & Pengetahuan & $\overline{\text { Perilaku }}$ \\
\hline \multirow{3}{*}{ Pengetahuan } & $\begin{array}{l}\text { Correlation } \\
\text { Coefficient }\end{array}$ & 1,000 &, $416^{* *}$ \\
\hline & $\begin{array}{c}\text { Sig. } \\
\text { (2-tailed) }\end{array}$ & . &, 000 \\
\hline & $\mathrm{N}$ & 80 & 80 \\
\hline \multirow[t]{3}{*}{ Tau_b } & $\begin{array}{l}\text { Correlation } \\
\text { Coefficient }\end{array}$ &, $416^{* *}$ & 1,000 \\
\hline & $\begin{array}{c}\text { Sig. } \\
\text { (2-tailed) }\end{array}$ &, 000 & . \\
\hline & $\mathrm{N}$ & 80 & 80 \\
\hline
\end{tabular}

Berdasarkan tabel 2, dapat diketahui bahwa nilai signifikansi pada variabel tersebut sebesar 0,000 dan nilai koefisien korelasi sebesar 0,416 yang berarti pada variabel pengetahuan memiliki hubungan sedang dan signifikan dengan perilaku dalam pendaftaran tanah wakaf. Hasil tersebut menunjukkan terdapat indikator yang kurang sesuai, yaitu riwayat pendidikan Nazhir yang tidak bisa digunakan sebagai tolok ukur pengetahuan pendaftaran tanah wakaf.

Tabel 3. Hasil Uji Korelasi Sikap dengan Perilaku

\begin{tabular}{cccc}
\hline & & & Perilaku \\
\hline & Sikap $\begin{array}{c}\text { Correlation } \\
\text { Coefficient }\end{array}$ & 1,000 &, $453^{* *}$ \\
\hline $\begin{array}{c}\text { Sig. } \\
(2-\text { tailed }) \\
\text { Kendall's }\end{array}$ & $\cdot$ &, 000 \\
Tau_b & Correlation & 80 & 80 \\
\hline & \begin{tabular}{c} 
Coefficient \\
\cline { 2 - 4 }
\end{tabular} &, $453^{* *}$ & 1,000 \\
& $\begin{array}{c}\text { Sig. } \\
(2-t a i l e d) \\
\text { N }\end{array}$ &, 000 & $\cdot$ \\
& & 80 & 80 \\
\hline
\end{tabular}


Berdasarkan tabel 3, diperoleh nilai signifikansi sebesar 0,000 dan nilai koefisien korelasi sebesar 0,453 yang berarti pada variabel sikap memiliki hubungan sedang dan signifikan dengan perilaku dalam pendaftaran tanah wakaf. Artinya terdapat indikator yang menyatakan bahwa persepsi Nazhir dalam pendaftaran tanah wakafkurang baik.

\section{Uji Korelasi Berganda}

Pada penelitian ini uji korelasi berganda digunakan untuk mengetahui secara bersamasama hubungan antara pengetahuan dan sikap dengan perilaku Nazhir dalam pendaftaran tanah wakaf. Adapun hasil uji korelasi yang telah dilakukan dapat dilihat pada tabel berikut:

Tabel 4. Hasil Uji Korelasi Berganda Pengetahuan dan Sikap dengan

Perilaku Model Summary

\begin{tabular}{ccccc}
\hline Model & $\mathbf{R}$ & $\begin{array}{c}\mathbf{R} \\
\text { Square }\end{array}$ & Adjusted R Square & Sig. F Change \\
\hline 1 & $\mathbf{0 , 5 9 0}$ & 0,348 & 0,331 & 0,000 \\
\hline
\end{tabular}

Berdasarkan tabel 4, dapat diketahui bahwa nilai signifikansi sebesar 0,000 dan nilai koefisien sebesar 0,590. Artinya, pada variabel pengetahuan dan sikap memiliki hubungan sedang dan signifikan dengan perilaku dalam pendaftaran tanah wakaf.

\section{Hasil Pengujian Hipotesis dan Pembahasan}

\section{Hubungan Pengetahuan dengan Perilaku Nazhir dalam Pendaftaran Tanah Wakaf}

Penelitian ini menunjukkan hasil bahwa terdapat hubungan sedang dan signifikan antara pengetahuan dengan perilaku Nazhir dalam pendaftaran tanah wakaf. Artinya untuk mengukur pengetahuan tidak hanya diperoleh melalui pendidikan formal saja, namun juga dapat diperoleh melalui pendidikan nonformal. Sejalan dengan penelitian Handayani dan Kurnia (2015) yang menyatakan bahwa pengetahuan memiliki pengaruh dalam membentuk suatu persepsi sehingga menumbuhkan perilaku dalam diri seseorang. Adapun salah satu faktor yang dapat mengukur pengetahuan ialah melalui pendidikan. Namun, pendidikan yang dimaksud bukanlah pendidikan formal, melainkan pendidikan nonformal yang dapat diperoleh melalui sosialisasi, pelatihan, maupun kegiatan lainnya di luar kelas atau sekolah. Sehingga melalui pendidikan nonformal dapat menambah pengetahuan yang lebih luas. Berdasarkan karakteristik responden pada pendidikan terakhir diperoleh sebanyak 46\% Nazhir tanah wakaf di Kecamatan Krian berpendidikan terakhir SMA/SMK. Melalui hasil tersebut dapat dikatakan bahwa pendidikan tinggi maupun rendah tidak menjadi tolok ukur dalam menambah pengetahuan terkait pendaftaran tanah wakaf. Hal itu diketahui dari responden yang menyatakan bahwa pengalaman 
lebih diutamakan dalam mengelola perwakafan. Menurut Wawan dan Dewi (2014), pengalaman merupakan faktor utama untuk menambah pengetahuan Nazhir dalam pendaftaran tanah wakaf. Pengalaman dapat diperoleh melalui kegiatan lain seperti pendaftaran tanah kepemilikan, pengelolaan tanah, pengelolaan aset wakaf lainnya yang pernah dilakukan. Sehingga pengalaman lebih berpengaruh daripada pendidikan formal yang dimiliki oleh Nazhir. Hal ini diperkuat oleh QS. Al-Ankabut Ayat 20, yang artinya sebagai berikut:

"Katakanlah: "Berjalanlah di (muka) bumi, maka perhatikanlah bagaimana Allah menciptakan (manusia) dari permulaannya, kemudian Allah menjadikannya sekali lagi. Sesungguhnya Allah Maha Kuasa atas segala sesuatu”.

Pada ayat tersebut menjelaskan bahwa manusia diperintahkan untuk melakukan pengamatan dan pemikiran seluruh alam semesta. Sehingga dengan jelas melalui pengamatan terhadap suatu hal dapat menjadikan sebuah pengalaman untuk menambah pengetahuan yang dimiliki.

Tingkat religiusitas Nazhir atau ketaatan seseorang dalam meyakini suatu agama yang dianutnya juga menjadi faktor pendukung untuk menambah pengetahuan dalam pendaftaran tanah wakaf. Tingkat religiusitas dapat diukur melalui kepercayaan terhadap agama bahwa tanah yang telah diwakafkan harus bersertifikat demi keamanan aset wakaf di kemudian hari. Berdasarkan penelitian yang telah dilakukan, Nazhir di Kecamatan Krian Kabupaten Sidoarjo memberikan respon positif terhadap pernyataan dimana pendaftaran tanah wakaf merupakan salah satu bentuk untuk menjaga keamanan aset tanah wakaf melalui bukti sertifikat wakaf. Pernyataan tersebut sesuai dengan Kitab Syarah Al-Yaqutun Nafis yang menyatakan bahwa setiap harta benda yang telah diwakafkan sebaiknya dicatat dalam bentuk sertifikat demi masa depan harta benda wakaf agar tidak menimbulkan permasalah di kemudian hari (Mundzir, 2018).

Sehingga diduga bahwa pengetahuan yang dibekali dengan pengalaman, religiusitas, dan pendidikan nonformal akan meningkatkan perilaku atau tindakan Nazhir dalam mendaftarkan tanah wakaf. Sebaliknya, apabila perilaku pendaftaran tanah wakaf tidak dibekali oleh pengetahuan yang cukup maka keinginan Nazhir untuk mendaftarkan tanah wakaf yang dikelolanya akan kecil. 


\section{Hubungan Sikap dengan Perilaku Nazhir dalam Pendaftaran Tanah Wakaf}

Penelitian ini menunjukkan hasil bahwa terdapat hubungan sedang dan signifikan dari sikap dengan perilaku Nazhir dalam pendaftaran tanah wakaf. Penelitian ini sejalan dengan penelitian yang dilakukan oleh Zuhrinal dan Nawawi (2011), yang menyatakan bahwa sikap memiliki hubungan signifikan dengan keinginan mahasiswa dalam mengeluarkan wakaf tunai. Adapun sikap tersebut diperoleh melalui kepercayaan serta keyakinan terhadap lembaga wakaf tunai sebagai pengelolanya. Keyakinan yang dimiliki seseorang merupakan sebuah faktor yang dapat memberikan sikap positif terhadap suatu objek. Pada penelitian ini keyakinan Nazhir di Kecamatan Krian Kabupaten Sidoarjo dalam pendaftaran tanah wakaf sangat baik. Hal itu diketahui melalui penelitian yang telah dilakukan bahwa Nazhir tanah wakaf di Kecamatan Krian memiliki keyakinan bahwa sertifikat wakaf sangat penting baik untuk saat ini maupun di masa yang akan datang.

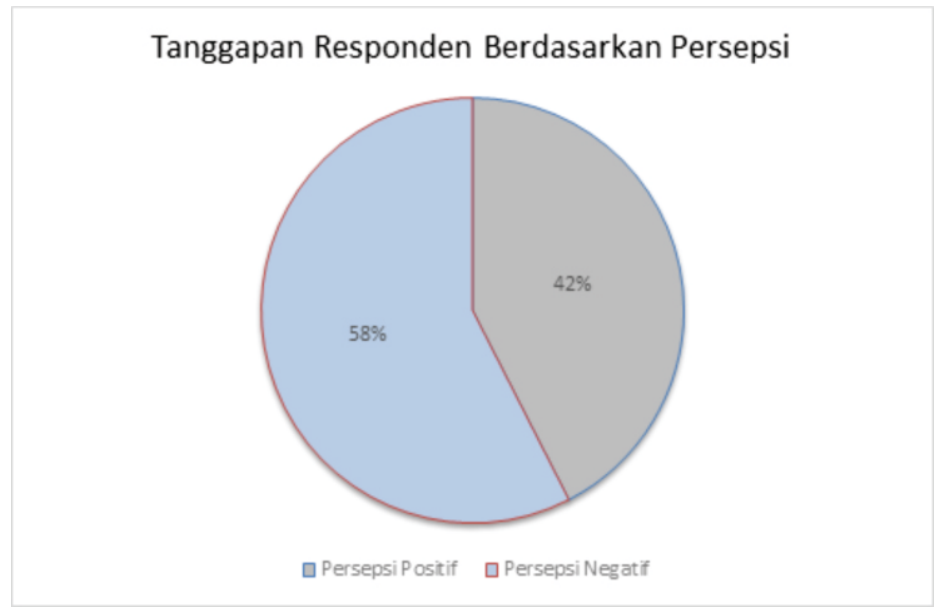

Diagram 1. Tanggapan Responden Berdasarkan Persepsi

Pada diagram 1, jumlah Nazhir yang memberikan persepsi negatif sebesar 58\% karena dalam prosedurnya membutuhkan waktu yang lama dan biaya yang cukup besar. Sehingga akta ikrar wakaf yang dibuat oleh Pejabat Pembuat Akta Ikrar Wakaf(PPAIW) sudah cukup sebagai bukti tertulis. Adapun beberapa Nazhir lainnya menyatakan biaya yang dikeluarkan sangat terjangkau, berbeda dengan pendaftaran tanah kepemilikan. Pernyataan tersebut diperkuat oleh Purboyo (2019) yang menyatakan bahwa sertifikasi tanah wakaf saat ini telah dipermudah dengan biaya ditanggungkan kepada setiap pimpinan cabang NU maupun Muhammadiyah. Namun, tidak semua sertifikat tanah wakaf ditanggung oleh pimpinan cabang sehingga apabila biaya tersebut ditanggungkan kepada pengurus tanah wakaf tentu akan mengeluarkan biaya yang tidak sedikit. Perbedaan persepsi diatas disebabkan karena biaya yang ditangungkan oleh pimpinan cabang NU maupun Muhammadiyah kurang merata. 
Perasaan seseorang, juga akan mempengaruhi sikap terhadap objek. Perasaan yang dimaksud ialah perasaan suka maupun tidak suka, atau perasaan tenang atau tidak tenang dalam objek yang diamati. Pada penelitian yang dilakukan, Nazhir di Kecamatan Krian Kabupaten Sidoarjo memiliki perasaan yang baik terhadap pendaftaran tanah wakaf. Dengan perasaan baik dapat menciptakan sikap positif bagi Nazhir dalam pendaftaran tanah wakaf. Perasaan tenang yang dirasakan oleh Nazhir didasari dengan peraturan pendaftaran tanah wakaf yang sudah diatur dalam perundang-undangan.

Sehingga dapat disimpulkan bahwa Nazhir sudah memiliki sikap positif dalam pendaftaran tanah wakaf. Sikap positif tersebut dapat diketahui melalui persepsi, keyakinan, dan perasaan yang baik pada pendaftaran tanah wakaf. Kemudahan administrasi tanah wakaf dan keterjangkauan biaya administrasi tanah wakaf merupakan faktor terpenting untuk mendorong persepsi positif dan meningkatkan hubungan sikap dengan perilaku Nazhir di Kecamatan Krian Kabupaten Sidoarjo dalam pendaftaran tanah wakaf. Hal ini diperkuat dengan QS. A-Qashash Ayat 84, yang artinya:

"Barangsiapa yang datang dengan (membawa) kebaikan, maka baginya (pahala) yang lebih baik daripada kebaikannya itu; dan barangsiapa yang datang dengan (membawa) kejahatan, maka tidaklah diberi pembalasan kepada orang-orang yang telah mengerjakan kejahatan itu, melainkan (seimbang) dengan apa yang dahulu merekakerjakan".

Ayat tersebut menjelaskan bahwa setiap orang yang bersikap baik pada hal yang baik maka akan menimbulkan perilaku yang baik dan mendapatkan balasan yang lebih baik dari apa yang telah dilakukannya. Sebaliknya, seseorang yang bersikap negaif terhadap hal yang baik dan berperilaku negatif terhadap hal baik maka akan mendapat balasan yang seimbang dengan perbuatannya.

\section{Hubungan Pengetahuan dan Sikap dengan Perilaku Nazhir dalam Pendaftaran Tanah Wakaf}

Urgensi daripada pendaftaran tanah wakaf sangat diutamakan pada setiap perwakafan. Tidak hanya tanah wakaf akan tetapi seluruh aset wakaf harus memiliki catatan sebagai bukti bahwa aset tersebut merupakan aset wakaf. Pencatatan tersebut harus dilakukan oleh pengelola beserta dengan wakif dan orang lain sebagai saksi. Pernyataan tersebut diperkuat oleh QS. AnNisa Ayat 58, yang artinya sebagai berikut: 
"Sesungguhnya Allah menyuruh kamu menyampaikan amanat kepada yang berhak menerimanya, dan (menyuruh kamu) apabila menetapkan hukum di antara manusia supaya kamu menetapkan dengan adil. Sesungguhnya Allah memberi pengajaran yang sebaik-baiknya kepadamu. Sesungguhnya Allah adalah Maha Mendengar lagi Maha Melihat".

Ayat diatas menjelaskan bahwa adanya pencatatan dalam setiap kegiatan muamalah merupakan suatu amanat kepada yang berhak menerimanya. Sehingga dalam perwakafan, seorang Nazhir adalah orang yang ditunjuk sebagai penerima wakaf dimana Nazhir yang harus mengelola dan memiliki pengetahuan serta sikap positif dalam hal perwakafan.

Penelitian ini menunjukkan bahwa pengetahuan dan sikap memiliki hubungan sedang dan signifikan dengan perilaku Nazhir di Kecamatan Krian Kabupaten Sidoarjo dalam pendaftaran tanah wakaf. Hal ini menunjukkan bahwa adanya pengetahuan serta sikap yang dimiliki Nazhir terkait pendaftaran tanah wakaf akan meningkatkan perilaku atau tindakan Nazhir dalam mendaftarkan tanah wakaf. Pengetahuan dan sikap Nazhir dalam pendaftaran tanah wakaf akan lebih baik apabila dibekali dengan berbagai pelatihan yang menunjang Nazhir untuk berperilaku positif terhadap tanah wakaf. Adapun pelatihan tersebut dapat diperoleh melalui lembaga yang berwenang dalam hal perwakafan maupun Kementerian Agama setempat.

Hasil penelitian ini sejalan dengan penelitian yang dilakukan oleh Juliana (2017) yang membahas mengenai perilaku Nazhir dalam pemberdayaan wakaf produktif, bahwa pengetahuan dan sikap terhadap perilaku Nazhir memiliki tingkat signifikansi sebesar 98,9\% untuk menerapkan wakaf produktif. Artinya, hubungan antarvariabel perilaku Nazhir dan pengetahuan dan juga sikap benar-benar signifikan. Berbeda halnya dengan penelitian yang dilakukan oleh Maulida (2013) yang menyatakan bahwa kontribusi pengetahuan terhadap perilaku seseorang masih kecil dibandingkan dengan variabel lainnya. Perilaku seseorang akan lebih baik apabila dibekali dengan adanya kajian, sosialisasi, maupun informasi mengenai perilaku beramal agar seseorang memiliki kesadaran terhadap apa yang akan dilakukan. Perilaku dalam pendaftaran tanah wakaf merupakan tugas yang harus dilakukan oleh Nazhir demi keamanan aset tanah wakaf di kemudian hari. Adapun pengetahuan pendaftaran wakaf dapat diperoleh melalui informasi maupun pelatihan. Sehingga dapat memilah persepsi yang baik maupun buruk dan berdampak pada perilaku untuk melalukan pendaftaran tanah wakaf. 


\section{KESIMPULAN}

Berdasarkan penelitian yang telah dilakukan, diperoleh hasil bahwa pengetahuan memiliki hubungan sedang dan signifikan dengan perilaku Nazhir di Kecamatan Krian Kabupaten Sidoarjo dalam pendaftaran tanah wakaf. Sikap memiliki hubungan sedang dan signifikan dengan perilaku Nazhir di Kecamatan Krian Kabupaten Sidoarjo dalam pendaftaran tanah wakaf, dan jika diuji secara bersama-sama, pengetahuan dan sikap berhubungan sedang dan signifikan dengan perilaku Nazhir di Kecamatan Krian Kabupaten Sidoarjo dalam pendaftaran tanah wakaf.

Penulis berharap lembaga perwakafan dapat memberikan sosialisasi kepada masyarakat khususnya bagi pengelola wakaf dalam pendaftaran tanah wakaf, sehingga dapat menambah pengetahuan yang dimiliki oleh masyarakat terkait prosedur pendaftaran tanah wakaf. Penulis juga berharap agar peneliti lain dapat menambah atau menggunakan variabel lain yang dapat memperkuat hubungan perilaku dalam pendaftaran tanah wakaf. Nazhir sebagai pengelola wakaf memiliki peran penting dalam perwakafan. Sehingga dari penelitian ini dibutuhkan Nazhir yang profesional agar tanah wakaf memiliki kekuatan hukum yang jelas dan tidak terbengkalai.

\section{DAFTAR PUSTAKA}

Abdullah, J., \& Qodin, N. (2014). Penyelesaian Sengketa Wakaf dalam Hukum Positif. Jurnal Zakat dan Wakaf, 1 (1), 37-54. DOI: 10.21043/ziswaf.v1i1.1524

Azwar, S. (2002). Sikap Manusia Teori dan Pengukurannya. Edisi kedua. Yogyakarta: Pustaka Pelajar.

Direktorat Pemberdayaan Zakat dan Wakaf. (2019, Februari). Sistem Informasi Wakaf. Diambil dari siwak.kemenag.go.id

Fadhilah, N. (2011). Sengketa Tanah Wakaf dan Strategi Penyelesaiannya. De Jure, Jurnal Syariah dan Hukum, 3 (1), 71-85. DOI: 10.18860/j-fsh.v3i1.1321

Gerungan, W. A. (2004). Psikologi Sosial. Edisi ketiga. Bandung: Refika Aditama.

Habibi, M. L., \& Yudha, A. T. R. C. (2017). Membangun Integrated Takaful dan Wakaf Model dalam Upaya Meningkatkan Kemanfaatan Pemegang Polis. Al-Uqud: Journal of Islamic Economics, 1 (2), 139-155. DOI: 10.26740/al-uqud.v1n2

Hamidi. (2010). Metode Penelitian Kualitatif. Malang: UMM Press.

Handayani, R. P., \& Kurnia. T. (2015). Analisis Persepsi Masyarakat Kota Bogor Terhadap Wakaf Tunai. Jurnal Syarikah: Jurnal Ekonomi Islam, 1 (2), 61-70. DOI: 10.30997/jsei.v1i2.256

Haqqy, A. M, Busaini, H., \& Rois, I. (2017). Perilaku Wakif dalam Mewakafkan Tanahnya untuk Kesejahteraan Masyarakat. JEBI: Jurnal Ekonomi dan Bisnis Islam, 2 (1), $97-$ 110. DOI: $10.15548 /$ jebi.v2i1.71 
Hazami, B. (2016). Peran dan Aplikasi Wakaf dalam Mewujudkan Kesejahteraan Umat di Indonesia. Jurnal Analisis: Jurnal Studi Keislaman, 16 (1), 173-204. DOI: 10.24042/ajsk.v16i1.742

Huda, N., Anggraini, D., Rini, N., Hudori, K., \& Mardoni, Y. (2014). Akuntabilitas Sebagai Sebuah Solusi Pengelolaan Wakaf. Jurnal Akuntansi Multiparadigma, 5 (3), 485-497. DOI: $10.18202 / \mathrm{jamal} / 2014.12 .5036$

Hendrawati, D., \& Islamiyati. (2018). Penyelesaian Sengketa Tanah Wakaf yang Tidak Tersertifikasi di Wilayah Pesisir Utara Jawa Tengah. Jurnal Masalah-Masalah Hukum, 47(1), 71-80. DOI: 10.14710/mmh.47.1.2018

Juliana, H. (2017). Hubungan Pengetahuan dan Sikap dengan Perilaku Nazhir di Kecamatan Stabat Kabupaten Langkat dalam Pemberdayaan Wakaf Produktif. Jurnal AtTawassuth: Jurnal Ekonomi Islam, 2 (1), 1-22.

Junaidi, M. M. (2015). Efektifitas Pensertifikatan Tanah Wakaf di Kabupaten Pasuruan (Studi di Departemen Agama Kabupaten Pasuruan). Jurnal Hukum. 2-25.

Mundzir, A. (9 Desember 2018). Hukum Tanah Wakaf Tidak Disertifikat yang Berakibat Sengketa. Diperoleh dari https://islam.nu.or.id/post/read/100064/hukum-tanahwakaf-tidak-disertifikatkan-yang-berakibat-sengketa.

Mardeli. (2016). Teori Kompensasi Emosi. Jurnal Tadrib: Jurnal Pendidikan Agama Islam. 2 (1), 1-30.

Maulida, S. (2013). Pengaruh Religiusitas Terhadap Perilaku Beramal (Charitable Behavior) Masyarakat Kota Yogyakarta. JESI: Jurnal Ekonomi Syariah Indonesia, 3 (1), 1-16. DOI: $10.21927 /$ jesi.2013.3

Mustadi, A. (2016). Penanaman Nilai-Nilai Agama dalam Pembentukan Sikap dan Perilaku Siswa Sekolah Dasar Islam Terpadu Luqman Al-Hakim Yogyakarta. Jurnal Penelitian dan Evaluasi Pendidikan, 8(1), 1-15. DOI: 10.21831/pep.v811.2018

Pakpahan, D. R. (2017). Pengaruh Pengetahuan dan Sikap Terhadap Perilaku Masyarakat pada Bank Syariah di Wilayah Kelurahan SEI Sikambing D. At-Tawassuth: Jurnal Ekonomi Islam, 3 (3), 345-367.

Pratama, A. D. R., Muhyidin., \& Islamiyati. (2016). Perlindungan Hukum Terhadap Harta Benda Wakaf yang Tidak Didaftarkan Pada Kantor Pertanahan (Studi pada Putusan Nomor 393/pdt/2014/pt. Mdn). Diponegoro Law Journal, 5(2), 1-18.

Purboyo, M. R. (21 Maret 2019). Hindari Konflik Sertifikasi Tanah Wakaf Dipermudah. Diperoleh dari https://m.bisnis.com/amp/read/20190321/47/902682/hindari-konfliksertifikasi-tanah-wakaf-dipermudah

Saidi, M., Pagar., \& Jamil, M. (2018). Alih Fungsi Harta Wakaf Dalam Perspektif Fiqh Syafi'yiyah dan UU No. 41 Tahun 2004. AT-TAZAKKI: Jurnal Kajian Ilmu Pendidikan Islam dan Humaniora, 2 (1), 100-110.

Simamora, B. (2002). Panduan Riset Perilaku Konsumen. Jakarta: Gramedia Pustaka Utama.

Sugiyono. (2018). Metode Penelitian Kuantitatif. Bandung: Alfabeta.

Wawan, A., \& Dewi, M. (2014). Teori dan Pengukuran Pengetahuan, Sikap, dan Perilaku Manusia. Yogyakarta: Nuha Medika.

Zuhrinal, M., \& Nawawi. (2011). Kecenderungan Masyarakat Untuk Berwakaf Tunai (Studi Kasus Mahasiswa Fakultas Syariah IAIN Sumatera Utara). Jurnal Media Syariah: Wahana Kajian Hukum Islam dan Pranata Sosial, 13 (2), 213-226. DOI: 10.22373/jms.v1312.1789 